REFLECTIONS:

NEUROLOGY AND THE

HUMANITIES

Section Editor

Michael H. Brooke, MD

Robert J. Joynt, MD,

$\mathrm{PhD}$

Address correspondence and reprint requests to Dr. Robert J. Joynt, Department of Neurology, University of Rochester Medical Center, Box 673, 601 Elmwood Avenue, Rochester, NY 14642 Robert_joynt@urmc.rochester.edu
THE SILENT WITNESS AND CHARCOT'S HAT I have often commented about Sherlock Holmes's peculiar fund of knowledge as an encyclopedic acquaintance of sensational and criminal literature; a restricted command of chemistry confined to an exhaustive familiarity with identification of various types of blood, poisons, tobacco, and soil; and a detailed knowledge of the British legal code. However, I was aghast at his spotty knowledge of classic and modern literature; for instance, he did not recognize the name of Thomas Carlyle. But he would occasionally quote long passages from the Shakespearean sonnets.

I was musing about this while enjoying a pipeful, when Mrs. Hudson entered with an envelope for Holmes. Holmes picked up the envelope, sniffed at it, and pronounced, "This is from a woman of impeccable elegance, and she is writing from the seaside. Her penmanship is hurried, and, I would guess, conveys some degree of anxiety. I am intrigued about what she has to say."

Holmes opened the letter and read it quickly, and passed it to me. I read it silently: "Dear Mr. Holmes, Your name was given to me by Admiral Welch, who says he is an old friend of yours. My brother John and I have suffered a double tragedy. One is his illness, which, I am afraid, you cannot help us with. The second is a robbery, which deprives us of our main income. Please, Mr. Holmes, see it in your heart to assist the local police in their investigations. Thus far, they have no further information. Imploringly, Elizabeth Carstairs."

I turned to Holmes. "Not much information here, Holmes?"

"No, but it is not to be ignored. Admiral Welch did me a great favor at one time and I would be less than a scapegrace if I could not return his favor. Watson, I am not sure of the location of the Seaside Palace Hotel, do you know anything about it?"

"I know it well. Prior to embarkation from London to Afghanistan, 3 of my fellow officers and I pooled our meager resources for a final outing at Sea Cove, which is the location of the Seaside Palace Hotel. It is a beautiful, small hamlet on the North Sea catering to the wealthy. It is dominated by the hotel and surrounded by expensive restaurants and shops,

\section{Reflections for April}

small hotels, and cottages to let. We booked one for 4 days, but the prices were so dear that we had to leave after 3 , but we did have one sumptuous meal at the hotel."

"It sounds like a pleasant enough place. I will telegram Mrs. Carstairs and tell her of our arrival by the early afternoon train from King's Cross, then we will proceed to the hotel. Are you up for it, Watson?"

"Certainly, Holmes, I can wash this stultifying London air out of my system."

We arrived the next afternoon at the residential suite of rooms of Mrs. Carstairs and her brother. We made our introductions, and went through the usual pleasantries. Holmes sat across from Mrs. Carstairs and suggested she get on to the details of the robbery.

Mrs. Carstairs, as Holmes had surmised, was a woman of elegant tastes in her manner and bearing, appearance, and dress.

"Mr. Holmes, our family grew up a few miles from this village. We did our shopping here and spent many a happy holiday on the shore. Our father died 10 years ago and our mother 1 year ago. I was widowed 5 years ago and have 2 children, a son and daughter, both away at school. My brother, John Randolph, was a career Royal Naval officer, rising to the rank of Captain. About 6 weeks ago, he suffered a small stroke of apoplexy, followed by others, and was honorably discharged from the Royal Navy. Because of his illness and his love of the sea, we decided to move into these quarters. There is a naval station at the edge of the village, and at least one of his colleagues visits him daily. Unfortunately, his condition has deteriorated and now he lies almost like a dead man."

"Two nights ago, I checked on my brother and then took coffee in the dining room with my friends. I was gone less than an hour, but when I returned to my rooms I found that we had been robbed. After our parents died, my brother and I came into considerable wealth, which was mostly in the form of jewelry. It had all been stolen and the local police have no further information. Unfortunately, Mr. Holmes, it constitutes the bulk of our money for the future. Even more dreadful, and this is due to my improvidence, with the move and my brother's illness, I had not placed the jewelry in our bank vault. Further, 
due to the various covenants and codicils of the wills of family members, the jewelry was uninsured at the time of the robbery. Mr. Holmes, can you see the dreadful situation in which we find ourselves?"

"Mrs. Carstairs, let me ask you a few more questions. Who knew about the presence of the jewelry?"

"Mr. Holmes," she said, "for years we have dealt with Mr. John Carter, who runs a very fine jewelry shop in this village. We have had implicit trust in him, he is a family friend and visited us on holidays, and he is the godfather of my son. He has been here on several occasions, cataloging all pieces for insurance purposes. Obviously, he is distraught over the whole situation."

"And, Mrs. Carstairs, can you tell me the makeup of the suite, and any more details about the robbery?"

"My brother's bedroom is on the side facing the sea with a door out to the balcony that runs across the front of the hotel. My bedroom is at the back of the suite and looks out over the garden. We have this large reception and sitting room and off of it is the dining room with adjoining kitchen facilities. We have several closets and 2 small bedrooms for the children when they are home from school."

She went on, "The evening of the robbery, the thief came in through my brother's bedroom, his diminished state of awareness being, unfortunately, well known. The lock was broken open. The thief immediately went to my bedroom and located the jewelry, and left, probably the same way he entered."

Holmes leaned over and touched Mrs. Carstairs' hand. "Mrs. Carstairs, I know this has been a most difficult story you have told us, but with your permission and in your presence, Dr. Watson and I would like to visit your brother briefly."

They quietly proceeded to the bedroom and stood by the brother's side. He lay as if dead with only an occasional gasping respiration. Mrs. Carstairs gently touched the forehead of her brother. His eyes opened slowly, he looked around the room, settled his eyes for a moment on us, and again closed his eyes as before. We stood for a moment. Holmes surveyed the room, walked over to the door, and briefly went out to the balcony. We then departed back to the sitting room.

Mrs. Carstairs said, "Our family doctor said he had never seen anything like it. What have you to say, Dr. Watson?"

"Nor have I," said I. "It is as if he is somewhat conscious but has no power of movement or speech to communicate. His breathing is slight and irregular, and I am afraid I must agree with your own doctor's opinion that he only has a few more days."

Mrs. Carstairs said, "Tomorrow morning one of his oldest friends, Commander Barnes, a fellow Officer, will visit him."
Holmes and I got up to go on to the guest rooms Holmes had ordered. Holmes asked Mrs. Carstairs, "Could you tell me the location of the jewelry shop run by your friend, Mr. Carter?” He quickly added, "I would like to speak with your local constable, and finally, where could I send a telegram?"

Mrs. Carstairs duly instructed Holmes on the locations, indicating that everything in the small village was only a few steps from each other.

Finally, in parting and after being instructed, Holmes asked Mrs. Carstairs for one other request.

"I wonder if I could join Commander Barnes in his visit to your brother. I certainly will not be intrusive."

"Certainly," said Mrs. Carstairs. "I am sure the Commander will not object. The officers usually come around 10:00 in the morning after inspections at the naval station. Perhaps you could drop up at half 9 for a cup of tea after breakfast."

Holmes and I thanked our hostess, and went off to our rooms. Holmes excused himself and made an appointment to meet me for dinner.

The next morning, Holmes turned up promptly at Mrs. Carstairs' suite. They shared breakfast tea, and at 10:00 AM, Commander Barnes showed up for his visit. He was a red-faced, jovial man, and was warmly welcomed by Mrs. Carstairs. She introduced Holmes and repeated his request to share the visit with her brother. The naval officer heartily consented, and Holmes and Barnes went off to the invalid's room. A half hour later they emerged, Commander Barnes expressed his condolences to Mrs. Carstairs, and Holmes indicated he would be busy but would communicate with her before the end of the day.

Holmes returned to his room and told me of the other visits he must make. I was delighted to have the day free to explore the seashore.

Holmes and I met later in the afternoon. Holmes indicated to me that his work was completed, and he would give his regards to Mrs. Carstairs, and reassure her that the stolen property would be restored in a short time.

Holmes and I took the early evening train. I had learned not to press Holmes on his methods, until Holmes picked a propitious time to reveal them. Holmes instead discussed the geology of the east coast and pointed out peculiar rock formations in the landscape. We reached London just as the late summer day was fading.

There was idleness the next few days. Holmes did some desultory stroking of the violin. I settled in to catch up on the news I had missed the last few days. On the third day, a telegram and a long letter arrived. Holmes surveyed them and picked up the telegram. 
He read, "Dear Mr. Holmes, We have caught the thief and his accomplice, recovered the jewelry, and have returned it to Mrs. Carstairs. Your colleague Higgins spotted the Carstairs brooch on Jean Clarke, a lady friend of Richard Davis's. Davis is a clerk in the jewelry store of John Carter. We searched the flat of Miss Clarke and found all the jewelry wrapped in a hotel towel and deposited at the bottom of a dust bin. Again, my thanks for all the information you supplied us.

Sincerely, Jack Turner, Constable."

"Holmes, that is wonderful, but who is your colleague Higgins?"

Holmes replied, "He is one of my irregulars, that group of boys I sometimes employ for various jobs."

"A colleague, indeed, they are nothing but a bunch of ragamuffin street boys," I scoffed.

Holmes explained, "Watson, Higgins is the most observant and unobserved tracker I have ever seen. He makes the best Scotland Yards operative stand out like a peacock in full panoply of color."

"But how did you gather the necessary evidence?" I inquired.

Holmes looked at me with some mild disdain. "Why from the one witness, of course, Captain John Randolph. He was, after all, the only one that saw the thief enter through his bedroom and, thus, the only one that could provide an accurate description."

"Holmes, you are playing me for the fool," I objected. "Randolph was at death's door and could neither speak nor write nor move a muscle."

Holmes returned, "Actually, Commander Barnes, Captain Randolph, and I had a most illuminating conversation for about a half hour. Communication did not seem to be a problem. The Captain gave us precise information about the thief so that he was readily identifiable."

"Watson, remember that the brother and his visitor were senior naval officers. I assumed, correctly, that they both were highly proficient in the Morse code, which had been used for decades in land telegraphy and for a few years by radio waves. It is used most frequently by the Royal Navy for ship to ship communication by the Aldis or signal lamp. The dots and dashes lend themselves to short and long eye blinks. I asked Captain Randolph the questions, he blinked the code to Barnes, and I got my answer. The description of the thief who had passed through the bedroom was excellent: tall, red-haired, mustache, glasses, with a limp of his right leg. I had seen the same man the day before as a clerk in Mr. Carter's shop. Unfortunately, Carter's fidelity to the family was exceeded by his garrulity, so the thief knew where to find the jewelry."
Holmes continued, "Watson, if you will go back to your schoolboy days, you may recall reading the great novel, The Count of Monte Cristo, by Alexandre Dumas pére. In it was a character Noirtier de Villefort, a devoted Bonapartist. If you remember, he had a stroke of apoplexy, which resulted in the character only being able to move his eyes and forehead. However, with this he developed a means of communication with a few members of his family and with his faithful servant Barrois. This situation was not unlike that of our unfortunate Captain Randolph."

Here again, I was astounded at the bits of information that Holmes could bring up at times. It surprised me for I neither saw such a book in Holmes's collection nor did I ever see him sitting and reading a novel. But I protested to Holmes, "Certainly the fanciful license taken by an author would scarcely be admissible by a magistrate, when he heard the description of the condition of Captain Randolph. The opposing advocates would immediately dismiss this bit of evidence, unless there were some solid medical report backing it up."

"And that is what I expect in the envelope I received today." He opened the envelope and took out several sheets of paper. "Ah, yes. This, I believe, will buttress my case considerably. Watson, you may have heard of the French physician, Jean-Marie Charcot? Would you quote him as a reliable medical expert?"

I reddened. "Charcot is the greatest expert on neurologic conditions in the world! But how could you know him?"

"Interestingly," said Holmes, "I met him in Paris 3 years ago with my brother Mycroft. Mycroft, as you know, hates to travel, moving only from his own flat to the foreign office, to the Diogenes Club, and back again. He was assigned to go to Paris on an important mission by the foreign office, and Mycroft asked me to accompany him. One of the higher officials in the foreign office in Paris had developed some nervous affliction, and because the official possessed some delicate secrets at that time, Mycroft was sent to be there during his illness and then bring him back to London. The foreign office had called in Dr. Charcot to see the patient, and Mycroft and I were in attendance. The redoubtable Dr. Charcot turned up one evening wearing a rather disreputable great coat and a high and dusty stovepipe hat. The consultation went well, Charcot assured us it was a minor affliction and that the patient could return to London without difficulty. We fell into an idle conversation for a few minutes. Charcot seemed to hear of some of my exploits, by courtesy of your writings."

Holmes continued, "He said that he was in need of a detective, as he had lost a valuable manuscript he 
finished 2 weeks before. He said he had looked everywhere but it was not to be found."

"I offered to help and pointed out to Charcot that when he came in and took off his long stovepipe hat and laid the top on the table, it had fallen over twice in the same direction before he, disgustedly, turned it over and placed it on its wide brim. I picked it up, searched the inner lining of the hat, and pulled out several pieces of paper. Charcot shouted 'Mon Dieu! That is the manuscript."'

"I said to Charcot, 'I suspected something when I saw the imbalance of the hat, and beside, I have the same habit of using my hat as a repository for documents."”

"Charcot thanked me gratefully, and said, 'I hope that some day I may return the favor,' and he has.”

"Here, Watson, read the letter and I will translate the enclosed document."

I read, "My dear Mr. Holmes. I am glad I can return your favor. Yes, I have seen cases as you described. In fact, not too long ago while presiding in the chair at the Anatomic Society, there was a very good description of a similar situation. It was reported by M. Darolles in Progrès médical, 1875, 3:629-630. I have marked out the place on the report."

"It concerned a white woman of 36. The woman had a series of apoplectic attacks. You can translate the report at leisure but let me quote the essential facts: On 5 March the day after admission, the physician found the patient in the decubitus position on her back with her limbs fully extended. There was no deviation of the eyes or rotation of the head. The patient could no longer make noise of any kind. It was only by the movements of her eyes that she could respond to our questions and express her symptoms. Through this communication she was able to explain to us that she did not lose consciousness during the night, skin sensitivity was conserved, and the headache had not reappeared. She could not in the slightest way move her tongue, which henceforth remained in the buccal cavity, behind her incisors. It was only with difficulty that she was able to lower her jaw, as levator muscles presented with faint rigidity and made a weak protrusion under her skin. Sincerely, Jean-Marie."

Holmes quickly jumped to the end of the report noting the autopsy was done the eighth of March. In essence, the large basilar artery was occluded. "As I remember from my anatomic studies, this artery supplies the upper part of the brainstem. Thus, Watson, I think we have conclusive medical and legal evidence to back up our case."

A few days later Holmes received a letter from Mrs. Carstairs. It went as follows: "My dear Mr. Holmes, I am so grateful to you for all of your efforts. The family jewels are restored, and I can assure you they are now properly insured and resting in our bank vault. It will provide for my means, and for the education of the children. Unfortunately, my brother died 2 days ago. He was buried this morning in our parish church. He was buried with full naval honors. All of his old colleagues were present. It was very moving, but sad. It was a merciful death."

"Again, my thanks. Although we did not talk about a fee for your services, I am enclosing a check which I hope will be appropriate for your efforts. Warmly, Mrs. Elizabeth Carstairs.”

Holmes laid the letter on the desk, put the check in his vest pocket after a quick perusal, and muttered, "Indeed, more than appropriate."

I turned to Holmes and said, "Now what will we do, Holmes?"

Holmes straightened up, and said, "I have 2 social engagements to arrange. First, I must contact the irregulars' favorite pub, lay on slavers of fish and chips, provide tankards of ale, and plum duff. Second, I must arrange a more sedate setting, where you and I will sample the delicate and flaky poached Dover sole, a crisp and dry Riesling, and my favorite figgy pudding."

\section{ACKNOWLEDGMENT}

The author thanks the Estate of Sir Arthur Conan Doyle for permission to use place and personal names; Dr. Milton Medeiros for pointing out the appropriate medical article; and Dr. Richard Satran and Patrick Joynt for help in translation. 


\title{
Neurology
}

\author{
Reflections for April: The silent witness and Charcot's hat \\ Robert J. Joynt \\ Neurology 2011;76;1358-1361 \\ DOI 10.1212/WNL.0b013e31821527cd
}

\section{This information is current as of April 11, 2011}

\section{Updated Information \&}

Services

Permissions \& Licensing

Reprints including high resolution figures, can be found at: http://n.neurology.org/content/76/15/1358.full

Information about reproducing this article in parts (figures,tables) or in its entirety can be found online at:

http://www.neurology.org/about/about_the_journal\#permissions

Information about ordering reprints can be found online:

http://n.neurology.org/subscribers/advertise

Neurology ${ }^{\circledR}$ is the official journal of the American Academy of Neurology. Published continuously since 1951, it is now a weekly with 48 issues per year. Copyright Copyright (? 2011 by AAN Enterprises, Inc.. All rights reserved. Print ISSN: 0028-3878. Online ISSN: 1526-632X.

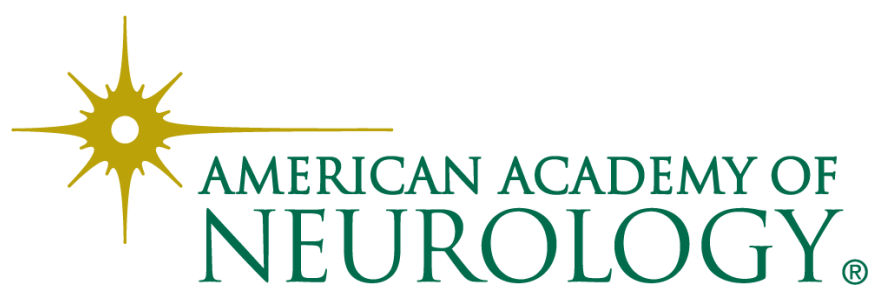

